\title{
Undergraduate education in Brazil: the students' curricular perspective of Dental care training
}

\author{
Cléa Adas Saliba Garbin*; Tania Adas Saliba**; Artênio José Ísper Garbin**; Lia Borges de Mattos \\ Custódio***; Suzely Adas Saliba Moimaz* $^{*}$
}

\author{
* Full professor, Department of Children and Social Dentistry, \\ UNESP Araçatuba \\ ** Associated Professor, Department of Children and Social \\ Dentistry, UNESP Araçatuba \\ *** Master's degree candidate in Preventive and Social Dentistry, \\ Graduated Program, UNESP Araçatuba
}

Received November 25, 2018. Approved December 21, 2018.

\begin{abstract}
Contemporary Dental practice poses many challenges to the dental surgeon; thus, the academic training must enable practitioners to deal with the constant changes in the techniques and the difficulties in clinic's management. This study aimed to analyze the students' perceptions on their training competencies. This was a cross-sectional study carried out with 89 undergraduate students in the final years of training in Dentistry at a public university in the State of São Paulo in 2018. The students responded to a semistructured instrument composed of 17 items on skills adapted from the National Dental Examining Board and the students' perception on the dimensions of importance, confidence in the execution and contribution of the training environments (i.e., classroom and clinical setting) was analyzed for each of the skills assessed. Importance, confidence and training environments were evaluated according to the Likert's scale, ranging from 1 (no relevance) to 5 (extremely relevant). The data analysis was performed at a significance level of 5\%. There were statistically significant positive correlations between importance and confidence for competencies related to patient records, treatment planning, health determinants, pulp pathologies, and restorative and surgical procedures. It was also observed that skills related to management/administration had the lowest mean for confidence. It was concluded that students understand that competency is essential for their training high as well as confidence to perform clinical procedures. However, administrative procedures need to be improved.
\end{abstract}

Descriptors: Education, Dental. Problem-Based Learning. Clinical Competence. Academic Success.

\section{INTRODUCTION}

The contemporary dental practice brings numerous challenges to the dental surgeon; thus academic training should enable practitioners to deal with the constant changes in the techniques and management of dental clinic, including providing their patients with quality oral healthcare based on evidence ${ }^{1}$.

The creation of a learning environment that stimulates the development of behaviors and 
skills, especially self-evaluation, is of factual importance for the formation of health professionals. Undergraduate students should be encouraged to develop these skills from their training to enable them to be aware of the current state of their knowledge, including recognizing and acknowledging their own technical limitations ${ }^{2}$. For the American Dental Association (ADA), undergraduate education programs should prepare students to take responsibility for their own learning as well as to know how to apply new knowledge throughout the career as a health professional. The lifelong learning skills include the self-assessment of their own learning needs ${ }^{3}$.

In Brazil, the curricular guidelines for dentistry propose that: "Undergraduate dental education requires that the student/professional dentist has a generalist, humanistic and critical profile and be thoughtfully trained to work at all levels of healthcare based on technical and scientific rigor, including qualification to carry out oral health activities ethically and legally for the population, and to understand the social, cultural and economic reality of their environment by aiming their action at the transformation of the reality to benefit the society" ${ }^{\prime}$. Therefore, to train professionals with this profile, the faculty member occupies a prominent place in the diverse teaching-learning practices focused on the student ${ }^{5,6}$. The $9^{\text {th }}$ article of the curricular guidelines proposes that "Undergraduate dental education should have a pedagogical project, built collectively, focused on the student as a subject of learning and supported by the professor as a facilitator and mediator of the teaching-learning process. This pedagogical project should provide the student with full and proper education through an articulation between teaching, research, extension, and assistance" $" 4,6$. Thus, to consider this training of human resources in healthcare, the Brazilian government uses the periodic assessments of higher level courses (ENADE) to measure the quality of academic education ${ }^{7,8}$. It is possible to observe the existing distortions in pedagogical projects or even in their execution, from the analysis of Enade ${ }^{7,9}$. However, ENADE has been subject to several criticisms, since it does not measure the perception of the students, but rather their knowledge about certain subjects.

The need to evaluate teaching is born from the dynamic transformation of knowledge as well as from the society's search for acquisition of this knowledge by professionals. In the countries of North America, the assessment model adopted emphasizes training through "skills and abilities essential to the beginning of dental practice" ${ }^{15,10}$, thus the Association of Canadian Faculties of Dentistry and the National Dental Examining Board (NDEB) describe "skills and abilities"11 for the training of the dental surgeon to assist in the improvement and monitoring of the curriculum structure $^{12}$.

Competency can be defined as a synthesis of knowledge, skills and attitudes which, when integrated, enables the individual to improve the use of cognitive and technical resources to diagnose, treat and provide benefit, thus decreasing patient morbidity and cost to institutions ${ }^{5}$. The construction of a competencybased curriculum necessarily entails the development of a reliable and valid assessment system, containing several elements such as written tests, observation in practice settings and professional behavior through attitudes ${ }^{13}$. Thus, the continuous need to evaluate the training of human resources in health and the use of diversified methodologies for this purpose has been shown to be timely. The objectives of this study were to analyze the student's perception on the importance of each competency, confidence in achieving each competency, identification of any relationship between competency and 
confidence as well as on the contribution of the training environments (i.e. classroom and clinical setting) for each competency.

\section{METHODOLOGY}

This was a cross-sectional study carried out with 89 students in the final years of training in dentistry at a public university in the State of São Paulo in 2018. The research was approved by the local research ethics committee (CAAE: 92746218.6.0000.5420; Protocol number: 2.812.547).

The students responded to a semistructured instrument composed of 17 items on skills (table 1) adapted from the NDEB ${ }^{11}$. The students' perception on the dimensions of importance, confidence in the execution and contribution of the training environments (i.e., classroom and clinical setting) was analyzed for each of the skills assessed, as shown in Schönwetter's study ${ }^{12}$. Likert's scale, ranging from 1 (no relevance) to 5 (extremely relevant), was used to measure the students' perception on their undergraduate education. Quantitative data analysis was performed by using the Epi Info software version 7.2 for Windows ${ }^{\circledR}$ ("EpiInfoTM | CDC") ${ }^{14}$, whereas distribution of frequencies, analysis of the results and association tests were carried out by using the Bioestat software 5.3 ("Bioestat - version 5.3") ${ }^{15}$ at a significance level of $5 \%$.

\section{RESULTS}

All the 17 competencies presented to the students were positively assessed regarding the dimension of importance, with the highest mean values being associated with management skills of the dental clinic.

As for confidence (table 1), it was observed that competencies in which the students had the lowest rates are also associated with administrative areas. However, although items
$\# 10$, \#14 and \#16 were not related to the dimension of confidence, they were referred to clinical practice such as prescription drugs, diseases pertaining to dental pulp and prosthetic rehabilitation.

The contribution of the training environment (table 1), particularly the classroom, to the competencies related to clinical procedures had the highest mean values. Item \#13 stands out as it shows the great difficulty in all training environments, which is associated with a lack of confidence among the students.

There were statistically significant positive correlations between importance and confidence in items \# 5, \# 6, \# 8, \# 11, \# 14, \# 15.

Table 2 presents information on the discrepancy between importance and confidence. It was observed that the highest values are associated with administration of the clinic/dental office (items \#2, \#3, \#4). As for the training environment (table 1), these same items had the smallest means, and two of them are below the median. It was also observed in Table 2 that the issues with the smallest discrepancy are associated with clinical procedures, which had the highest means for clinical training environment.

\section{DISCUSSION}

In this study investigating the students' perception on the competencies in their training, it was observed that the mean values related to the dimension of importance were high. This finding demonstrates the students' comprehension of the relevance of the content of their undergraduate education, which is also corroborated by Schönwetter et al. ${ }^{12}$ and Whitney et $\mathrm{al}^{10}$.

The undergraduate course aims to prepare students to become experienced and qualified professionals to deal with the challenges of clinical practice ${ }^{16}$. Faculty-centered pedagogy, 
Table 1. Distribution of undergraduate students' perception according to importance, confidence and contribution of classroom and clinical training environments

\begin{tabular}{|c|c|c|c|c|c|}
\hline \multirow{2}{*}{ Competence } & \multirow{2}{*}{$\begin{array}{l}\text { Importance } \\
\text { Mean (SD) }\end{array}$} & \multirow{2}{*}{$\begin{array}{l}\text { Confidence } \\
\text { Mean (SD) } \\
\end{array}$} & \multirow{2}{*}{$\begin{array}{c}\text { Classroom } \\
\text { Mean (SD) } \\
\end{array}$} & \multirow{2}{*}{$\begin{array}{c}\text { Clinic } \\
\text { Mean (SD) } \\
\end{array}$} & \multirow[t]{2}{*}{ Correlation } \\
\hline & & & & & \\
\hline $\begin{array}{l}\text { 1. Perform clinical, radiographic and tissue examination of the maxillofacial complex with normalities and } \\
\text { abnormalities. Request additional tests, if necessary }\end{array}$ & $4,96(0,26)$ & $4,22(0,81)$ & $4,24(0,93)$ & $4,70(0,65)$ & 0,09 \\
\hline 2. Complete financial planning: determination of default rate, forecast of revenue and expenses & $4,84(0,50)$ & $3,07(1,20)$ & $3,21(1,33)$ & $2,84(1,59)$ & 0,10 \\
\hline 3. Perform the hiring / dismissal of auxiliary staff in the Dental office & $4,61(0,70)$ & $3,09(1,25)$ & $3,13(1,42)$ & $2,74(1,58)$ & 0,15 \\
\hline 4. Knowledge of municipal, state and federal legislation for the beginning of Dental practice & $4,76(0,50)$ & $3,31(1,19)$ & $3,83(1,33)$ & $3,18(1,59)$ & 0,05 \\
\hline 5. Keeping patient records accurate, complete and confidential & $4,93(0,70)$ & $4,69(1,25)$ & $4,48(1,42)$ & $4,36(1,58)$ & $0,37^{\mathrm{c}}$ \\
\hline $\begin{array}{l}\text { 6. Make the treatment plan and, if necessary, modify it during the course of treatment. Obtain written consent } \\
\text { from patients, including acceptance of the treatment plan, and modification of the initial treatment plan }\end{array}$ & $4,90(0,52)$ & $4,46(1,00)$ & $4,31(1,10)$ & $4,51(1,44)$ & $0,39^{c}$ \\
\hline $\begin{array}{l}\text { 7. Recognition of the patient in states of fear and anxiety with a view to minimizing treatment damage and } \\
\text { possible liability in the civil and criminal spheres of the Dental Surgeon }\end{array}$ & $4,79(0,55)$ & $3,99(0,83)$ & $3,97(0,99)$ & $4,06(1,05)$ & 0,16 \\
\hline $\begin{array}{l}\text { 8. Present and discuss options for treatment with information of financial values, form of payment, forecast of } \\
\text { time, considering the autonomy of choice of the patient }\end{array}$ & $4,78(0,56)$ & $3,88(0,94)$ & $3,66(1,21)$ & $3,73(1,29)$ & $0,25^{\mathrm{a}}$ \\
\hline $\begin{array}{l}\text { 9. Prevent transmission and self-contamination of infectious diseases following current infection control } \\
\text { guidelines. Recognize and institute procedures to prevent occupational risks related to the profession of } \\
\text { Dentistry. Manage waste produced in Dental practice }\end{array}$ & $4,97(0,18)$ & $4,46(0,69)$ & $4,39(0,83)$ & $4,48(0,77)$ & 0,11 \\
\hline $\begin{array}{l}\text { 10. Prescribing drugs observing indications and contraindications, drug dosages and routes of administration } \\
\text { of drugs used in Dentistry }\end{array}$ & $4,91(0,29)$ & $3,91(0,90)$ & $4,43(0,78)$ & $4,31(0,90)$ & 0,08 \\
\hline $\begin{array}{l}\text { 11. Recognize the determinants of health in individuals and populations and the role of Dentists in health } \\
\text { promotion, including the disadvantaged. Provide risk education and prevention of oral diseases and injuries by } \\
\text { encouraging behavioral change }\end{array}$ & $4,60(0,72)$ & $4,24(0,85)$ & $4,20(1,02)$ & $4,18(1,06)$ & $0,53^{\mathrm{c}}$ \\
\hline $\begin{array}{l}\text { 12. Obtain and interpret Medical, Dental, and Psychosocial history, including a review of systems as } \\
\text { necessary and assess physical or psychosocial conditions that may affect Dental administration }\end{array}$ & $4,80(0,53)$ & $4,08(0,88)$ & $4,16(0,96)$ & $4,29(0,98)$ & $0,25^{\mathrm{a}}$ \\
\hline 13. Recognize and treat patients with orofacial pain and/or dysfunction & $4,84(0,45)$ & $3,58(1,00)$ & $3,76(1,1)$ & $3,82(1,20)$ & $-0,05$ \\
\hline $\begin{array}{l}\text { 14. Recognize and treat the conditions and pathologies of the pulp. Differentiate and indicate capping of } \\
\text { endodontic treatment }\end{array}$ & $4,85(0,41)$ & $3,93(0,97)$ & $4,26(0,91)$ & $4,36(0,88)$ & $0,27^{b}$ \\
\hline $\begin{array}{l}\text { 15. Diagnose and treat dental caries, defects and aesthetic problems. Indicate when the restoration is justified, } \\
\text { using direct and indirect techniques to reestablish the dental form and function minimizing the loss of dental } \\
\text { structure and preserving the vitality of the tooth }\end{array}$ & $4,92(0,31)$ & $4,55(0,66)$ & $4,58(0,72)$ & $4,69(0,58)$ & $0,41^{\mathrm{c}}$ \\
\hline $\begin{array}{l}\text { 16. Diagnose, plan and treat partially and completely edentulous patients with prosthetic needs. Including the } \\
\text { forecast for total, partial and removable dentures }\end{array}$ & $4,87(0,40)$ & $3,94(0,86)$ & $4,35(0,84)$ & $4,37(0,82)$ & 0,13 \\
\hline $\begin{array}{l}\text { 17. Indicate and perform surgical procedures including procedures for the treatment of orofacial trauma. } \\
\text { Diagnose and treat periodontal diseases, including surgical procedure }\end{array}$ & $4,89(0,41)$ & $3,62(0,99)$ & $4,02(1,11)$ & $3,96(1,15)$ & $0,27^{\mathrm{b}}$ \\
\hline
\end{tabular}


Table 2. Variation between "confidence" and "importance" in students' perception

\begin{tabular}{|c|c|c|}
\hline & Competence & Discrepancy \\
\hline \multirow{5}{*}{ Largest } & $\begin{array}{l}\text { 2. Complete financial planning: determination of default rate, forecast of } \\
\text { revenue and expenses }\end{array}$ & 1,78 \\
\hline & 3. Perform the hiring / dismissal of auxiliary staff in the dental office & 1,52 \\
\hline & $\begin{array}{l}\text { 4. Knowledge of municipal, state and federal legislation for the beginning of } \\
\text { dental practice }\end{array}$ & 1,45 \\
\hline & $\begin{array}{l}\text { 17. Indicate and perform surgical procedures including procedures for the } \\
\text { treatment of orofacial trauma. Diagnose and treat periodontal diseases, } \\
\text { including surgical procedure }\end{array}$ & 1,27 \\
\hline & 13. Recognize and treat patients with orofacial pain and/or dysfunction & 1,26 \\
\hline \multirow{5}{*}{ Minors } & $\begin{array}{l}\text { 9. Prevent transmission and self-contamination of infectious diseases following } \\
\text { current infection control guidelines. Recognize and institute procedures to } \\
\text { prevent occupational risks related to the profession of dentistry. Manage waste } \\
\text { produced in Dental practice }\end{array}$ & 0,51 \\
\hline & $\begin{array}{l}\text { 6. Make the treatment plan and, if necessary, modify it during the course of } \\
\text { treatment. Obtain written consent from patients, including acceptance of the } \\
\text { treatment plan, and modification of the initial treatment plan }\end{array}$ & 0,44 \\
\hline & $\begin{array}{l}\text { 15. Diagnose and treat dental caries, dental defects and aesthetic problems. } \\
\text { Indicate when the restoration is justified, using direct and indirect techniques } \\
\text { to reestablish the dental form and function minimizing the loss of dental } \\
\text { structure and preserving the vitality of the tooth }\end{array}$ & 0,37 \\
\hline & $\begin{array}{l}\text { 11. Recognize the determinants of health in individuals and populations and } \\
\text { the role of dentists in health promotion, including the disadvantaged. Provide } \\
\text { risk education and prevention of oral diseases and injuries by encouraging } \\
\text { behavioral change }\end{array}$ & 0,36 \\
\hline & 5. Keeping patient records accurate, complete and confidential & 0,25 \\
\hline
\end{tabular}

as well as lack of integration between different disciplines, lead to fragmentation of knowledge, lack of patient-centered education and difficulty to integrate contents for development of critical thinking and problem-solving skills ${ }^{17}$. The American Dental Education Association's Commission on Change and Innovation in Dental Education (ADEA CCI), in its report, described the traditional dental curriculum as being complicated and incoherent, without connections and clinical relevance, drawing attention to the need for integration between basic and clinical sciences ${ }^{18}$.

Elangovan et al. ${ }^{17}$ reported that $73 \%$ of the universities participating in the study had basic science training without integration/interaction with clinical disciplines, which promotes a training in which healthcare is neither comprehensive, nor generalist, nor patientcentered and nor disease-focused. In the practice, this curriculum-based approach allows the formation of super-specialized professionals who are not capable of integrating the different areas of knowledge. The university's pedagogical project from which the data were collected in Brazil is aimed at the vast experience of the students regarding the routine clinical practice, with low interaction between the different areas of knowledge. It was observed that administration/management of auxiliary staff or dental clinic office does not have significant influence on the undergraduate education of the 
students. This phenomenon can be seen in the mean values for the dimensions of confidence and training environment, which had the lowest values associated with these competencies. Murray et al. ${ }^{19}$ found that it is crucial to exposure undergraduate students to the competencies so that they can gain experience and the gaps in training reduced. It was observed that in the dimension of competence (item \#13), training environments had little contribution to knowledge acquisition. This phenomenon can also be observed in skills related to administration/management (items \#2, \#3, \#4 and \#8). Other studies ${ }^{10,12}$ also found similar results for training areas related to orofacial pain and administration/management tasks.

Critical thinking and problem-solving skills are essential components of the vocational training, whereas in the conventional training (e.g., explanatory class) the content transmission is passive as the student's experience is not enhanced and there is neither integration of different disciplines ${ }^{17}$ nor autonomy, thus making the learning process fully dependent on the faculty member ${ }^{20}$. Diversified teachinglearning practices are needed to enhance human resource training in healthcare. The problembased learning (PBL) is a methodology which promotes self-learning and enables students to acquire knowledge with an analytical approach by solving problems, whereas the case-based learning (CBL) allows an effective integration of different areas of knowledge ${ }^{21}$. Studies show that teaching methodologies using CBL and/or PBL is positively related to the development of skills in dental practice ${ }^{22,23}$. Postma and White found a positive association in the students' perception on the relevance of different teaching-learning approaches as they were exposed to a CBL methodolog $\mathrm{y}^{20}$.

The results of the present study point to didactic weaknesses in the academic training of dental education, demonstrating the need for more studies on students' perception and improvement of the curricular basis to train professionals with critical problem-solving skills in daily clinical practice.

\section{CONCLUSION}

From the analysis of the students' perceptions on their academic training, it was concluded that all of them reported to be positive for the item on importance, whereas the item on confidence had lower mean values compared to importance.

\section{ACKNOWLEDGEMENTS}

The authors acknowledge the Coordination of Improvement of Higher Education Personnel (CAPES) for its support.

\section{RESUMO}

O ensino de graduação no Brasil: a perspectiva do estudante sobre aspectos curriculares da prática odontológica

A prática odontológica contemporânea enseja inúmeros desafios ao cirurgião-dentista. Neste sentido, a formação acadêmica deve capacitar profissionais para lidar com a constante mudança e expansão de técnicas e os desafios na gestão da clínica. O objetivo neste estudo foi analisar a percepção do estudante sobre competências de sua formação. Trata-se de um estudo transversal realizado com 89 graduandos dos últimos anos de formação em Odontologia em uma universidade pública do Estado de São Paulo no ano de 2018. Os estudante foram avaliados segundo 17 competências de formação adaptadas do "National Dental Examining" por meio das dimensões "importância", "confiança" e também a contribuição dos ambientes de formação ("sala de aula" e "clínica") para cada competência. Os quesitos de importância, confiança e ambientes de formação (sala de aula e clínica) foram avaliados segundo a escala de Likert de 1 (sem relevância) até 5 (extremamente relevante). A análise dos dados foi realizada com nível de 
significância de 5\%. Observou-se correlação positiva entre "importância" e "confiança" estatisticamente significante nas competências relacionadas aos registros dos pacientes, plano de tratamento, determinantes em saúde, patologias da polpa, procedimentos restauradores $\mathrm{e}$ cirúrgicos. Também foi observado que as competências relacionas à gestão/administração possuem as menores médias na dimensão "confiança". Conclui-se que os estudantes entendem a importância das competências para sua formação e a confiança para execução dos procedimentos relacionados à clínica é elevada. Entretanto, o preparo para execução de procedimentos relacionados à gestão precisa ser aprimorados.

Descritores: Educação em Odontologia. Aprendizagem Baseada em Problemas. Competência Clínica. Sucesso Acadêmico.

\section{REFERENCES}

1. Lynch CD, Ash PJ, Chadwick BL, Hannigan A. Effect of community-based clinical teaching programs on student confidence: a view from the United Kingdom. J Dent Educ. 2010;74(5):510-6.

2. McMahan CA, Pinckard RN, Jones AC, Hendricson WD. Fostering Dental student self-assessment of knowledge by confidence scoring of multiple-choice examinations. J Dent Educ. 2014;78(12):1643-54.

3. Commission on Dental Accreditation. Selfstudy guide for dental education programs. Chicago: American Dental Association; 2018.

4. Brasil. Conselho Nacional de Educação. Camara de Educação Superior. Resolução CNE/CES 3, de 19 de fevereiro. 2002. [Cited: March 14, 2018]. Available at: http://portal.mec.gov.br/cne/arquivos/pdf/C ES032002.pdf.

5. Chambers DW. Toward a competency-based curriculum. J Dent Educ. 1993;57(11):790-3.
6. Garbin CAS, Saliba NA, Moimaz SAS, Santos KT. The role of universities in the training of health professionals. Rev ABENO. 2006;6(1):6-10.

7. Moimaz SAS, Amaral MA, Garbin CAS. Enade: uma análise quanti-qualitativa dos exames nacionais de Odontologia. Rev ABENO. 2017;17(1):97-108.

8. Brazil. Lei 9131/95. Altera dispositivos da Lei $\mathrm{n}^{\circ} 4.024$, de 20 de dezembro de 1961, e dá outras providências. Diário Oficial da União, 1995. [Cited: March 14, 2018]. Available at: http://www.planalto.gov.br/ Ccivil_03/leis/L9131.htm. Accessed: March 14, 2018.

9. Paiva GS. Avaliação do desempenho dos estudantes da educação superior: a questão da eqüidade e obrigatoriedade no Provão e Enade. Ensaio Aval Pol Públ Educ. 2008;16(58):31-46.

10. Whitney EM, Walton JN, Aleksejuniene J, Schönwetter DJ. Graduating dental students' views of competency statements: importance, confidence, and time trends from 2008 to 2012. J Dent Educ. 2015;79(3):322-30

11. National Dental Examining Board of Canada. Competencies for a beginning dental practitioner in Canada. 2005. [Cited: March 14, 2018]. Available at: https://ndebbned.ca/sites/ndeb/files/pdf/competencies_2 005-final.pdf. Accessed: March 14, 2018.

12. Schönwetter DJ, Law D, Mazurat R, Sileikyte R, Nazarko O. Assessing graduating dental students' competencies: the impact of classroom, clinic and externships learning experiences. Eur J Dent Educ. 2011;15(3):142-52.

13. Fernandes CR, Farias Filho A, Gomes JMA, Pinto Filho WA, Cunha GKF da, Maia FL. Currículo baseado em competências na 
residência médica. Rev Bras Educ Méd. 2012;36(1):129-36.

14. Centers for Disease Control and Prevention. Epi Info $^{\text {TM }}$. 2018. [Cited: March 14, 2018]. Available at: https://www.cdc.gov/epiinfo/ index. html.

15. Instituto de Desenvolvimento Sustentável Mamirauá. Bioestat - versão 5.3. 2018. [Cited: March 14, 2018]. Available at: http://www.mamiraua.org.br/pt-br/downloa ds/programas/bioestat-versao-53.

16. Howard KM, Stewart T, Woodall W, Kingsley K, Ditmyer M. An integrated curriculum: evolution, evaluation, and future direction. J Dent Educ. 2009;73(8):962-71.

17. Elangovan S, Venugopalan SR, Srinivasan S, Karimbux NY, Weistroffer P, Allareddy V. Integration of basic-clinical sciences, PBL, CBL, and IPE in U.S. dental schools' curricula and a proposed integrated curriculum model for the future. J Dent Educ. 2016;80(3):281-90.

18. Pyle M, Andrieu SC, Chadwick DG, Chmar JE, Cole JR, George MC, et al. The Case for change in dental education. J Dent Educ. 2006;70(9):921-4.

19. Murray FJ, Blinkhorn AS, Bulman J. An assessment of the views held by recent graduates on their undergraduate course. Eur J Dent Educ. 1999;3(1):3-9.

20. Postma TC, White JG. Developing students' clinical reasoning skills: correlates of perceived relevance of two teaching and learning approaches. Eur J Dent Educ. 2017;21(1):52-7.

21. Garvey MT, O'Sullivan M, Blake M. Multidisciplinary case-based learning for undergraduate students. Eur J Dent Educ. 2000;4(4):165-8.

22. Nadershahi NA, Bender DJ, Beck L, Lyon C, Blaseio A. An overview of case-based and problem-based learning methodologies for dental education. J Dent Educ. 2013;77(10):130-5.

23. Samuelson DB, Divaris K, Kok IJD. Benefits of Case-based versus traditional lecturebased instruction in a preclinical removable prosthodontics course. J Dent Educ. 2017;81(4):387-94.

\section{Correspondence to:}

Profa. Cléa Adas Saliba Garbin

e-mail: cgarbin@foa.unesp.br

Núcleo de Pesquisa em Saúde Coletiva - FOA

Rua José Bonifácio, 1193 Vila Mendonça

16015-050 Araçatuba/SP Brazil 